\title{
ISSN 2179-1120 \\ Indicadores para Avaliação de Áreas com Patrimônio Histórico, Cultural e Ambiental: Estudo de Caso na Antiga Fazenda Galo Branco em São José Dos Campos/SP
}

\author{
Gabriella Patto Xavier Gonçalves', Dra. Maria Dolores Alves Cocco² \\ 'Mestra pelo Programa de Pós-graduação em Ciências Ambientais da Universidade de Taubaté. \\ E-mail: arq.gpatto@gmail.com \\ 2 Doutora pela Università degli Studi di Roma'La Sapienza'. \\ E-mail:maria.cocco@unitau.com.br
}

Recebido em 29 de maio de 2017; Aceito em 17 de junho de 2017.

\begin{abstract}
Resumo
O Vale do Paraíba é uma região com população estimada de três milhões de habitantes, onde o grau de urbanização é de 93,54\%. Constituído pela união de 39 municípios, possui a concentração do maior conjunto de patrimônio histórico construído do estado de São Paulo, associado ao ciclo econômico do café. A região apresenta-se com um contexto complexo nas inter-relações históricas e tem sido alvo de diversas pesquisas que procuram a compreensão dos fatos históricos do passado que ajudem a identificar os valores culturais e ambientais do presente. Inclusa neste contexto, a presente pesquisa teve como objetivo principal elaborar novo padrão de inventariação, de caracterização e de classificação de patrimônio cultural dentro de área de preservação ambiental. O processo de desenvolvimento do estudo envolveu: a contextualização e a definição de categorias de patrimônio cultural; análise das referências teóricas e a normatização brasileira sobre o tema; a abordagem conceitual de patrimônio geomorfológico analisado com o contexto paisagístico; a elaboração de um sistema de indicadores levantados a partir do estudo de caso; seleção e definição de indicadores para caracterização de paisagem histórica; e a proposição de um instrumento metodológico prático e exequível para identificação de bens culturais ambientais.
\end{abstract}

Palavras-chave: Fazenda Galo Branco; Vale do Paraíba; Ciências ambientais.

\begin{abstract}
The Vale do Paraíba, a region which has a population estimated at 3 million inhabitants, whose urbanization level consists of $93,54 \%$, made by the conurbation of 39 cities, has the greatest set of historical patrimony of the state of São Paulo, related to the economic coffee cycle. The region features a complex context concerning its historical interrelations, which has been the study of a lot of researches to comprehend historical facts which might help identify cultural and environmental values of the present. In this context, the current research mainly aims at elaborating a new pattern of inventory, which characterizes and classifies the cultural patrimony within the environmental preservation area. The process to develop the study involved: contextualizing and defining cultural patrimony categories; analysis of the theoretical references and the Brazilian standardization about the subject; the conceptual approach of geomorphologic patrimony analyzed with regard to the landscape context; the elaboration of a system of indicators from the case-study; selecting and defining the indicators to characterize the historical landscape; and the proposition of a practical and feasible methodological instrument to identify cultural and environmental assets.
\end{abstract}

Keywords: Galo Branco farm; Vale do Paraíba; Environmentalsciences. 


\section{INTRODUÇÃO}

A compreensão evolutiva das ações antrópicas sobre um determinado território é fundamental para a valoração dos bens culturais ambientais. O patrimônio cultural, ou, como são identificados nesta pesquisa, os bens culturais, assume diferentes formas sobre o território quando associado aos componentes socioeconômicos de uma civilização: arqueológico, arquitetônico, etnológico e científico (PEREIRA, 2005).

Pesquisas a nível internacional sobre preservação de bens culturais ambientais têm provado que a conservação da herança deixada pelo homem tem sido uma questão relevante para o equilíbrio entre as atividades humanas e o meio ambiente (ALVES et al.,2006).

Da mesma forma que os recursos hídricos são considerados um bem fundamental para a sobrevivência do homem, segundo a Unesco (2012) a herança cultural é um conjunto de bens deixados pelos nossos antepassados, que para o equilíbrio das futuras gerações, a humanidade tem o dever de preservar e conservar.

No Brasil, grande parte do patrimônio cultural e ambiental sofre um processo de degradação decorrente do abandono das antigas áreas de assentamentos das cidades históricas. Dando lugar ao crescimento das novas estruturas urbanas de modo periférico, que comprometem as áreas verdes limítrofes das cidades e o equilíbrio entre o meio urbano ou construído e o meio natural, na área rural. No estado de São Paulo, na região do vale do Paraíba, temos muitos exemplos desde processo como as cidades de: Jacareí, Taubaté, Pindamonhangaba, Caçapava e a cidade de São José dos Campos.

As cidades do vale do Paraíba têm sua expansão econômica e territorial associado, por volta de 1850, à cultura do café. As construções das fazendas cafeeiras que espelham este ciclo econômico são consideradas patrimônio histórico rural paulista. Mas a ausência de um inventário global e acessível brasileiro, torna este patrimônio totalmente vulnerável junto com as suas grandes áreas, que englobam córregos e matas.

Dessa forma a presente pesquisa teve como objetivo principal elaborar novo padrão de inventariação, de caracterização e de classificação de patrimônio cultural dentro de área de preservação ambiental. Como estudo de caso a área selecionada foi à antiga fazenda Galo Branco remanescente século XIX, no município de São José dos Campos.

O processo de desenvolvimento da pesquisa envolveu: a contextualização e a definição de categorias de patrimônio cultural; análise das referências teóricas e a normatização brasileira sobre inventário; a abordagem conceitual de patrimônio geomorfológico analisado com o contexto paisagístico; a elaboração de um sistema de indicadores levantados a partir do estudo de caso; seleção e definição de indicadores para caracterização de paisagens históricas; e a proposição de um instrumento metodológico prático e exequível para identificação e aplicação em áreas consideradas de preservação cultural e ambiental.

Ao término da pesquisa pode-se observar a degradação dos recursos hídricos e paisagísticos que contribuem para a perda constante de informações sobre a área histórica. Mas o trabalho direciona a necessidade de um monitoramento constante como forma de salvaguarda do patrimônio cultural e ambiental existente e inventariado a partir desta pesquisa.

\section{REVISÃO DA LITERATURA}

\subsection{PADRÕES DE IDENTIFICAÇÃO DE BENS CULTURAIS AMBIENTAIS}


O processo de classificação e caracterização de um bem, seja ele de cunho cultural, arquitetônico, natural ou geomorfológico deve passar por metodologias específicas que direcionem a análise. Em consideração, é contemplada para análise a relação entre as atividades humana e o contexto, o que torna a investigação pouco complexa, por isso, milhares de pesquisadores por todo o mundo, estão diariamente aprimorando e incentivando esse tipo de pesquisa para que sejam criadas novas metodologias de investigação e identificação. Na maioria dos casos, é feita uma inventariação do patrimônio e para isso pode ser feita uma definição de categorias temáticas para esta finalidade conforme pode ser visto na Figura 1 (PEREIRA, 1995).

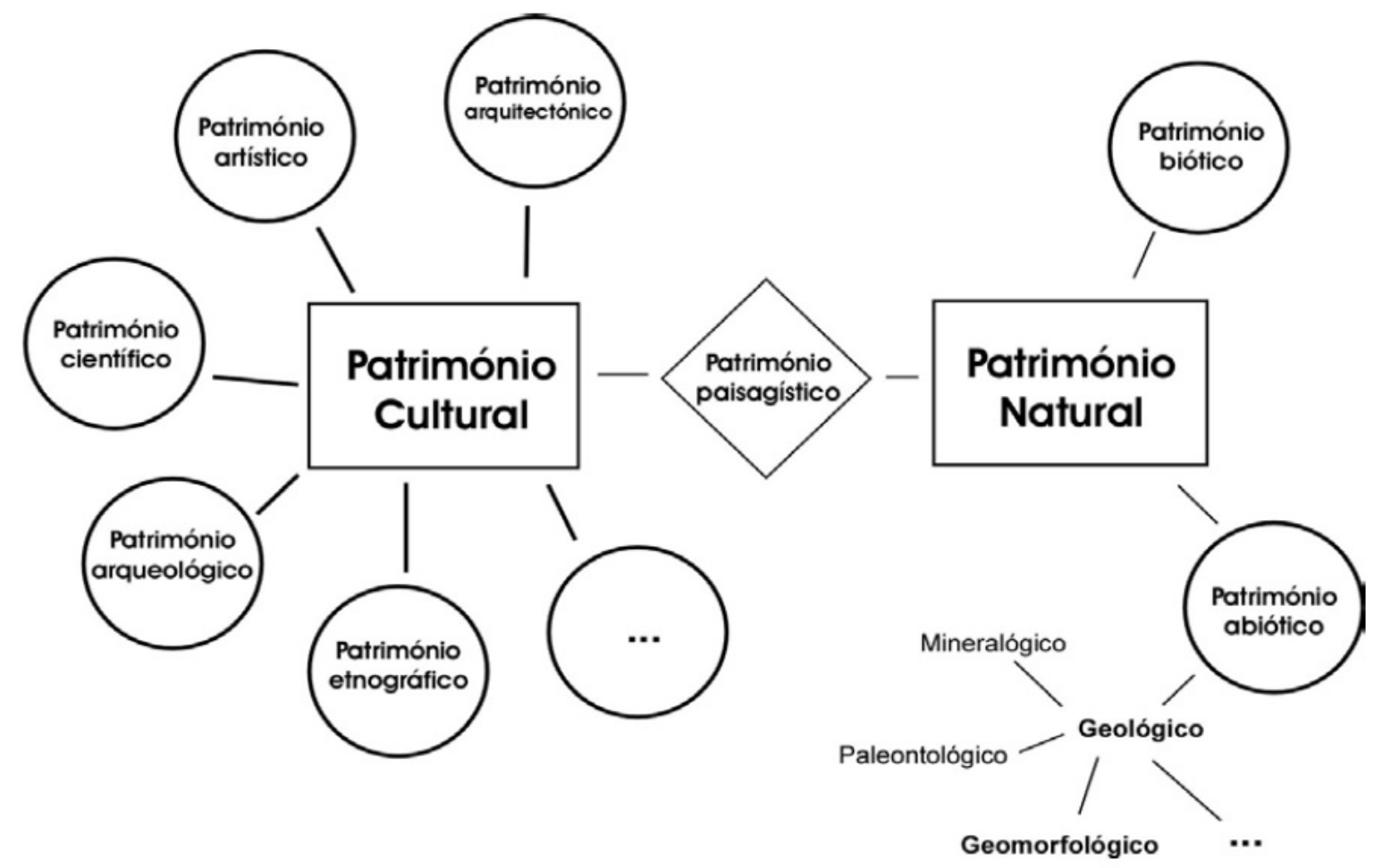

Figura 1: Proposta de enquadramento do patrimônio geomorfológico e do patrimônio paisagístico na organização temática do patrimônio. Fonte: Adaptado de PEREIRA, 2005

\subsubsection{INVENTARIAÇÃO}

A inventariação tem origem numa formulação e concepção de registro de patrimônio no caso de patrimônio cultural a concepção de preservação entra como centro da prática e como instrumento de salvaguarda de um bem (NOGUEIRA, 2007).

\subsubsection{CARACTERIZAÇÃO}

A caracterização do patrimônio paisagístico ambiental pode ser realizada através de elementos arquitetônicos e arqueológicos existentes na área de estudo e entornos, pois, através deles, com maior ou menor nível de importância, influenciam na interpretação da leitura da área e região. (OLIVEIRA \& FERRÃO, 2012)

A caracterização da paisagem cultural rural pode ser feita através do processo de identificação de propriedades rurais, baseado na visão de processos para compreensão da ocupação territorial destas fazendas, 
utilizando tabelas, mapas, fotos e levantamentos de campo, que permitam uma caracterização da área de estudo em maior escala (SCARIATO, 2009).

\subsubsection{CLASSIFICAÇÃO}

O critério de classificação do patrimônio exige primeiramente uma caracterização da área de estudo através de levantamento in loco, documentação, histórico, análises para então enquadrar a área de estudo ou objeto em questão na tabela de patrimônio existentes definido pela UNESCO como patrimônio cultural ou patrimônio natural (UNESCO, 2013).

A classificação é a primeira forma para o reconhecimento da importância dos bens culturais e ambientais através do registro dos dados sobre suas características principais físicas e identificação do estado da arte do patrimônio cultural a ser preservado (SEEC, 2014)

\subsection{NORMATIZAÇÃO BRASILEIRA PATRIMÔNIO CULTURAL E NATURAL: FEDERAL, ESTADUAL, MUNICIPAL}

Segundo a UNESCO (2013), na Convenção Geral para a Proteção do Património Mundial, Cultural e Natural de 1972, estabeleceu que "Património Natural" designa algo com características físicas, biológicas e geológicas extraordinárias; habitats de espécies animais ou vegetais em risco e áreas de grande valor do ponto de vista científico e estético ou do ponto de vista da conservação.

\subsubsection{TIPOS DE PATRIMÔNIO NATURAL}

1.Formações físicas e biológicas, ou grupos destas formações, de valor universal incalculável do ponto de vista estético e científico.

2. Formações geológicas e fisiográficas e áreas bem delimitadas que constituam o habitat de espécies animais ou vegetais em risco de valor incalculável do ponto de vista da ciência e da conservação

3. Sítios naturais ou áreas naturais bem delimitadas de valor universal incalculável do ponto de vista da ciência, da conservação ou da beleza natural.

Segundo a emenda constitucional numero 64 de 04 de fevereiro de 2010 da Constituição da República Federativa do Brasil no Artigo 216 que cita sobre o patrimônio cultural brasileiro, estabelece que o poder público, com a cooperação da comunidade, deve promover e proteger o "patrimônio cultural brasileiro". (BRASIL, 2010) Dispõe ainda que esse patrimônio é constituído pelos bens materiais e imateriais que se referem à identidade, à ação e à memória dos diferentes grupos formadores da sociedade brasileira, como sejam: as formas de expressão, os modos de criar, fazer, viver, as criações científicas, artísticas e tecnológicas, as obras, objetos, documentos, edificações e demais espaços destinados às manifestações artístico-culturais, os conjuntos urbanos e sítios de valor histórico, paisagístico, artístico, arqueológico, paleontológico, ecológico e científico. Segundo o Instituto do Patrimônio Histórico e Artístico Nacional (IPHAN), O patrimônio cultural não se restringe apenas a imóveis oficiais isolados, igrejas ou palácios, mas na sua concepção contemporânea se estende a imóveis particulares, trechos urbanos e até ambientes naturais de importância paisagística, passando por imagens, mobiliário, utensílios e outros bens móveis. Por este motivo é possível realizar uma das mais importantes distinções que se pode fazer com relação ao Patrimônio Cultural, pois sendo ele diferente das outras modalidades da cultura restritas apenas ao mercado cultural, apresenta interfaces significativas com outros importantes segmentos da economia como a construção civil e o turismo, ampliando 
exponencialmente o potencial de investimentos.

O patrimônio natural, primeiramente entende-se por alguma paisagem natural, envolvendo muitas vezes a geodiversidade e fatores bióticos de formação natural. Segundo o IPHAN (2004) duas posturas justificam as ações de preservação do patrimônio natural. A primeira de cunho ético fundamenta-se em um imprescindível valor humano, o respeito e a solidariedade que o homem, única criatura capaz de conhecer e compreender os fenômenos materiais e imateriais do universo, deve a todos os seres que o rodeiam, sobretudo às diferentes formas de vida com as quais compartilha o espaço e o tempo. A segunda, de cunho pragmático, origina-se do interesse e dependência do homem pelos recursos da natureza sem os quais não pode substituir. A preservação dos recursos naturais assegura ao homem a possível fruição desses bens, mesmo que ainda não conheça suas possíveis formas de utilização.

Em 1992, com o plano diretor decenal, lei complementar 16/1992, estabeleceu-se os alicerces para uma política pública clara e efetiva de proteção do patrimônio cultural instituindo a área de proteção do ambiente cultural - APAC, instrumento utilizado para a proteção do ambiente construído. Enquanto, área e preservação ambiental- APA passaria a ser utilizado apenas para o ambiente natural. A proteção do ambiente cultural (APAC) contribui para a formação da memória de uma cidade moderna. Na formação da identidade cultural urbana, cada bairro torna-se único e familiar aos seus moradores e frequentadores. Preservar esses ambientes, sua paisagem e fisionomia aproximam o patrimônio do cotidiano das cidades á vida de seus habitantes. (RIO DE JANEIRO, 1992)

\subsection{CONCEITO E PROCESSO DE IDENTIFICAÇÃO DE PAISAGEM HISTÓRICA}

O Método de pesquisa orientada a processos (POP) procura resgatar as dinâmicas de construção do conhecimento a partir da leitura do contexto e das diversas visões que se pode ter da realidade, trazendo à tona o olhar humano como principal agente de transformação desta mesma realidade que se enxerga, ou seja: o olhar que se tem sobre a realidade a partir de determinado contexto "pode não ser o único, nem o melhor, nem o mais correto", mas certamente compõe o arcabouço que permite uma visão holística a partir da permanente inclusão de outros olhares (ARGOLLO FERRÃO, 2008)

\subsection{CONCEITO E PROCESSO DE IDENTIFICAÇÃO DE PATRIMÔNIO GEOMORFOLÓGICO}

O conceito de patrimônio geomorfológico foi introduzido por Pereira (1995), com o exemplo do litoral sudoeste de Portugal. Entretanto, utilizado por outros autores, aparece normalmente como uma das categorias do património geológico, não sendo alvo de um processo de inventariação específica (CARVALHO, 1999). $\mathrm{Na}$ última década, e também fruto da atualidade internacional do tema, aumentou o número de investigadores interessados em desenvolver o tema.

O Patrimônio geomorfológico abrange diversas áreas da organização do patrimônio, é necessário que seja analisado o patrimônio como paisagem, realizando uma implementação do conjunto e não como nos casos de patrimônio arquitetônico, em que se faz análise do edifício. Normalmente são paisagens em grande escala e uma das tendências de investigação na área do patrimônio geomorfológico assenta nas relações entre as atividades humanas e o contexto geomorfológico onde se inserem. Na figura 2 temos um exemplo de metodologia para esta análise utilizado em Portugal. (ALVES et al., 2006) 


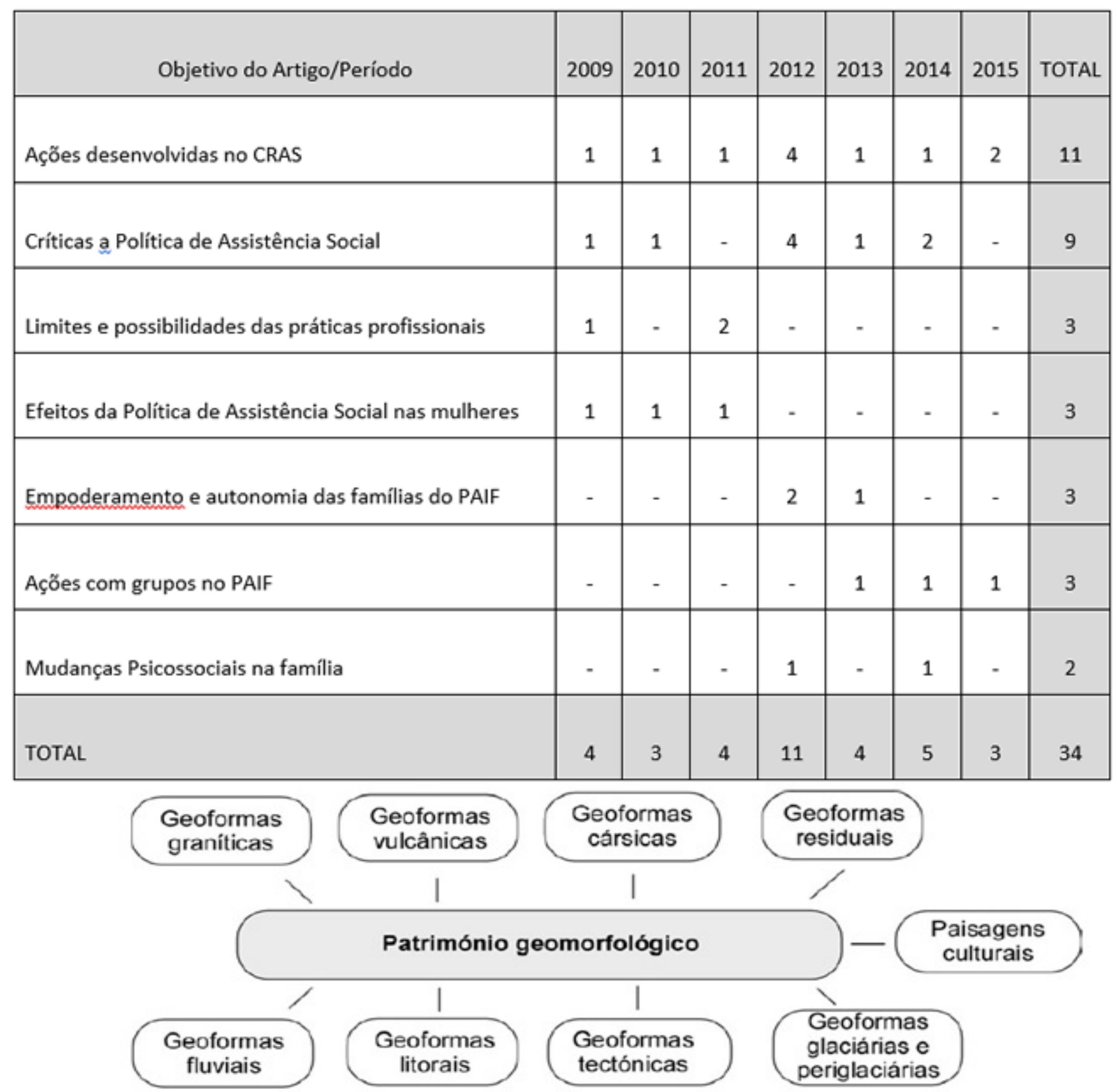

Figura 2: Categorias temáticas do patrimônio geomorfológico. Fonte: ALVES et al, 2006

Seguindo este pensamento, podemos notar que esta metodologia poderia ser aplicada e facilmente adaptada para diferentes áreas em análise de patrimônio geomorfológico ou ainda patrimônio natural de diferentes escalas, devido a sua fácil aplicabilidade em ressaltar indicadores. 


\subsection{CONCEITO E SELEÇÃO DE INDICADORES BENS CULTURAIS AMBIENTAIS}

Para o processo da seleção de indicadores adequados na avaliação de áreas consideradas histórico-culturais, segundo DEPONTI (2002):

Os indicadores sociais são menos trabalhados na literatura se comparados aos indicadores econômicos e ambientais. No entanto, não devem ser considerados menos importantes. A dificuldade de mensuração decorre da tendência a serem qualitativos e difíceis de definir com certa precisão.

Seguindo essa teoria, os indicadores para análise da área em questão devem ser levantados com base na percepção paisagística do local com visitas, registros fotográficos, análise de documentação histórica, história sobre fazendas produtoras cafeeiras e ainda as informações e conhecimentos de importância pela população da região.

Os indicadores são necessários para informar o estado de um sistema e também para intervir e corrigir o seu direcionamento a determinados objetivos identificando o sucesso de dada intervenção, entretanto a seleção dos indicadores para análise de patrimônio cultural, histórico dentro de áreas de preservação ambiental ambiental dentro de uma área em grande escala, se não for analisada ao longo do tempo, devido a constante transformação da paisagem (GALLOPIN, 1977).

\section{MATERIAL E MÉTODOS: CARACTERIZAÇÃO DA ÁREA}

\subsection{ESTRUTURAÇÃO DA DISSERTAÇÃO}

A estrutura da dissertação foi configurada no formato de etapas visando à facilitação de compreensão das informações coletadas no período de agosto a setembro de 2013 na área de estudo in loco na fazenda Galo Branco, no distrito Eugênio de Melo, no município de São José dos Campos, estado de São Paulo.

Os procedimentos metodológicos aplicados na pesquisa para levantamentos de dados na área de estudo basearam-se no enfoque participativo com acadêmicos do curso de arquitetura e urbanismo e de engenharia ambiental e sanitária da universidade de Taubaté, realizados segundo as etapas abaixo: 


\subsubsection{PROCEDIMENTOS METODOLÓGICOS APLICADOS NA PESQUISA PARA OS LEVANTA- MENTOS IN LOCO}

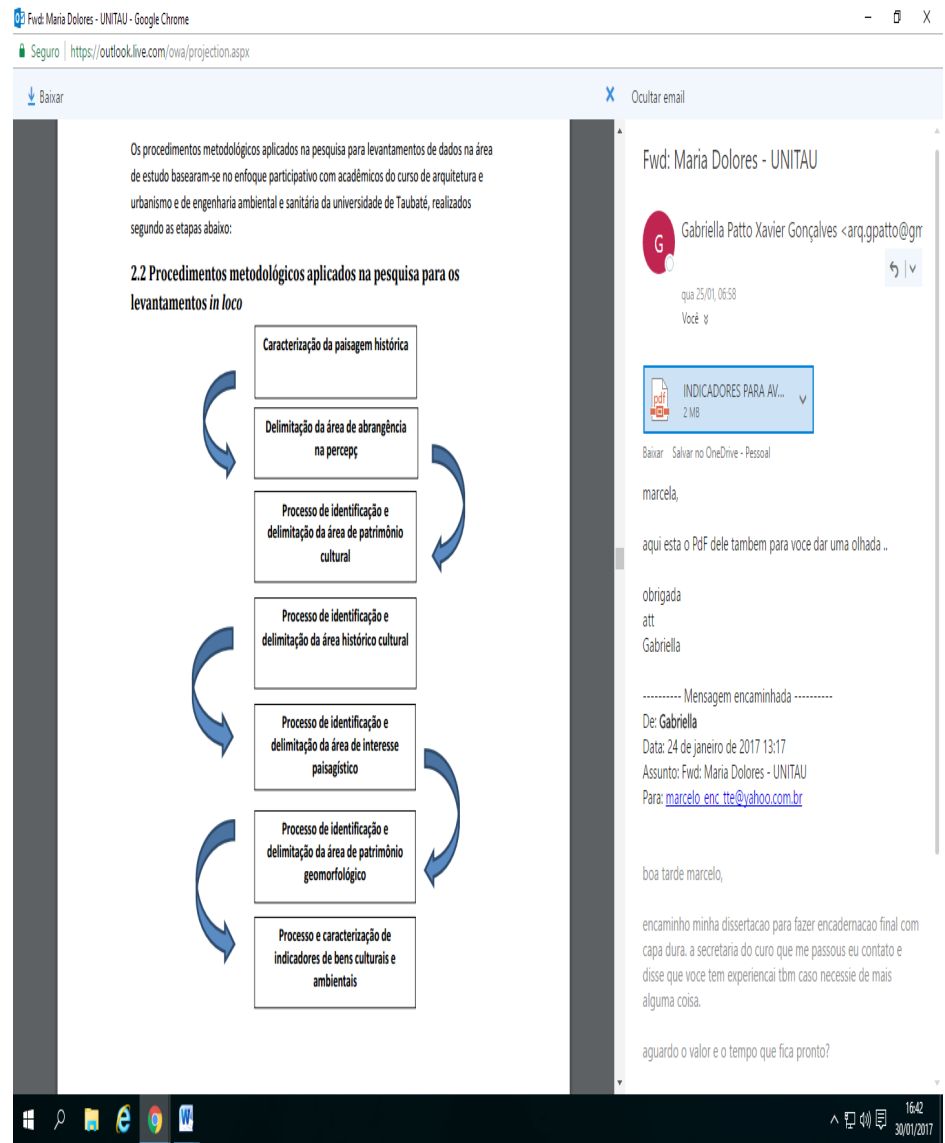

A caracterização da paisagem histórica:

A caracterização da paisagem histórica da área de estudo foi realizada com o método de análise através da iconografia histórica associada à documentação de registro do imóvel, no caso a centenária

A delimitação da área de abrangência na percepção visual:

A delimitação da área de abrangência na percepção visual foi aplicada baseada na teoria Gestalt que determina que as formas e a volumetria de um determinado objeto atraem as pessoas a partir da luz que irradia sobre o mesmo.

O processo de identificação e delimitação da área de patrimônio cultural:

O processo de identificação e delimitação da área de patrimônio cultural foi realizado com os parâmetros estaduais de proteção e de abrangência com a marcação de um raio que constitui o ambiente cultural.

O processo de identificação e delimitação da área histórico cultural:

O processo de identificação e delimitação da área histórico cultural foi realizado através do molde de categorias e de classificação patrimoniais apresentados por Pereira (2006) associados à interpretação da cartografia histórica da área de estudo.

O processo de identificação e delimitação da área de interesse paisagístico: 
O processo de identificação e delimitação da área de interesse paisagístico foi realizado com base nas condições existentes dos cenários naturais na área de estudo, com a valoração de seus atributos naturais numa determinada área de abrangência visual delimitada entre 50 metros a 300 metros, após a descrição das características observadas.

O processo de identificação e delimitação da área de patrimônio geomorfológico:

O processo de identificação e delimitação da área de patrimônio geomorfológico foi realizado através do molde de categorias apresentados por Alves (2006) associado à interpretação da cartografia histórica da área de estudo, dando ênfase as formas topográficas e suas interferências ou transformações ao longo da historia.

O processo e caracterização de indicadores de bens culturais e ambientais:

O processo e caracterização de indicadores de bens culturais e ambientais foram elaborados com base na seleção dos dados coletados e sintetizados numa tabela tendo como parâmetro a avaliação através mensuração de valores quantitativos e qualitativos por categorias.

\subsection{CARACTERIZAÇÃO DA ÁREA DE ESTUDO}

A área de estudo está localizada na região do Vale do Paraíba, na cidade de São José dos Campos no distrito de Eugenio de Melo que é umaregião industrializada e em crescimento que está em processo de conurbação com o município paulista de Caçapava e inserido na região metropolitana do Vale do Paraíba Paulista constituídapor 39 municípios, situada no cone leste do estado de São Paulo.

\subsubsection{LOCALIZAÇÃO GEOGRÁFICA}

O Vale do Paraíba está localizado no eixo Rio de Janeiro - São Paulo, compreendido entre os primeiros trechos do Rio Paraíba do Sul e as encostas das Serras do Mar e da Mantiqueira. Possui uma população de 2.406.735 habitantes, sendo 673.255 habitantes no município de São José dos Campos com uma área da unidade territorial $1.099,409 \mathrm{~km}^{2}$ (IBGE, 2013) Possui as seguintes coordenadas: Latitude $-23^{\circ} 10^{\prime} 45 \mathrm{~S}$ Longitude $-45^{\circ} 53^{\prime} 120$ (EMBRAPA, 2004). Localizada na zona leste de São José dos Campos, o distrito Eugenio de Mello tem 83665 habitantes (IBGE,2010). 


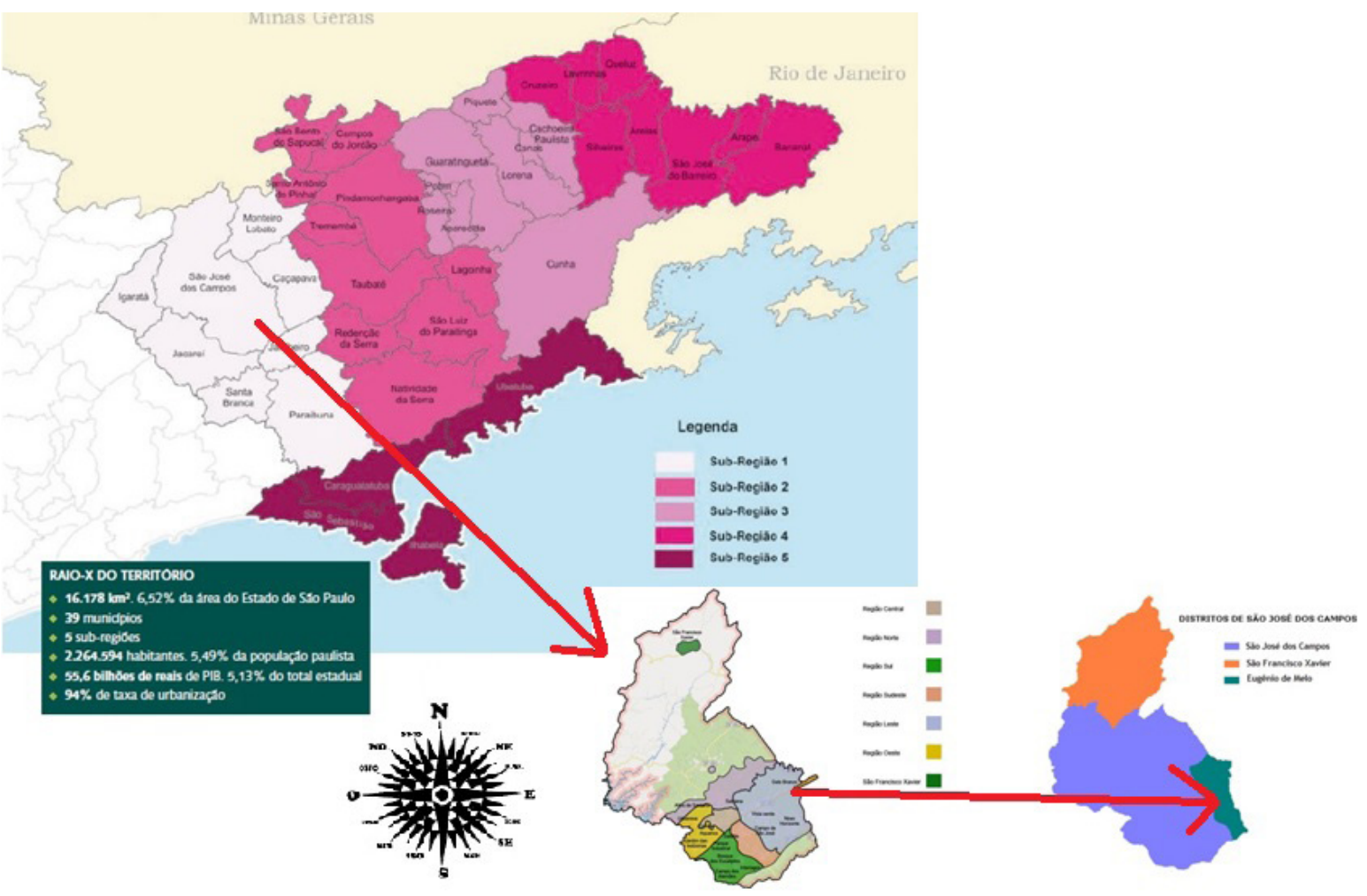

Figura 3: Mapa ilustrativo. Localização da área objeto de estudo. Caracterização da região metropolitana do Vale do Paraíba-SP, São José dos Campos e o distrito Eugenio de Mello. Fonte: Adaptado pela autora (censo 2010-2013 IBGE).

\subsubsection{ASPECTOS BIOFÍSICOS}

A região tem clima tropical de altitude e o município encontra-se a $550 \mathrm{~m}$ de altitude, a área de estudo situa-se na bacia hidrográfica do Rio Paraíba do Sul e estende-se por uma área de 55400 km² (IBGE,2006).

\subsubsection{ASPECTOS DA BACIA HIDROGRÁFICA DO RIO PARAÍBA DO SUL}

A bacia hidrográfica do Rio Paraíba do Sul abrange uma das mais desenvolvidas áreas industriais do País em São Paulo, Minas Gerias e Rio de Janeiro, arrecada cerca de $10 \%$ do PIB nacional e já assume um papel de destaque na implementação da Política Nacional de Recursos Hídricos. As águas do Rio Paraíba do Sul abastecem em torno de 15 milhões de pessoas.

No seu curso natural, o rio Paraíba do Sul, em território paulista, é ladeado pelas Serras do Mar e Mantiqueira. Após sua formação pela união dos rios Paraitinga e Paraibuna, passa por todo o Vale do Paraíba e adentra o estado do Rio de Janeiro, onde deságua no Oceano Atlântico, em São João da Barra, depois de ter percorrido $1.180 \mathrm{~km}$ (Amorim e Ferreira 2000). O córrego nossa senhora D’ajuda é um afluente da bacia do rio Paraíba do Sul e passa pela área de estudo, conforme podemos ver na figura 4. 


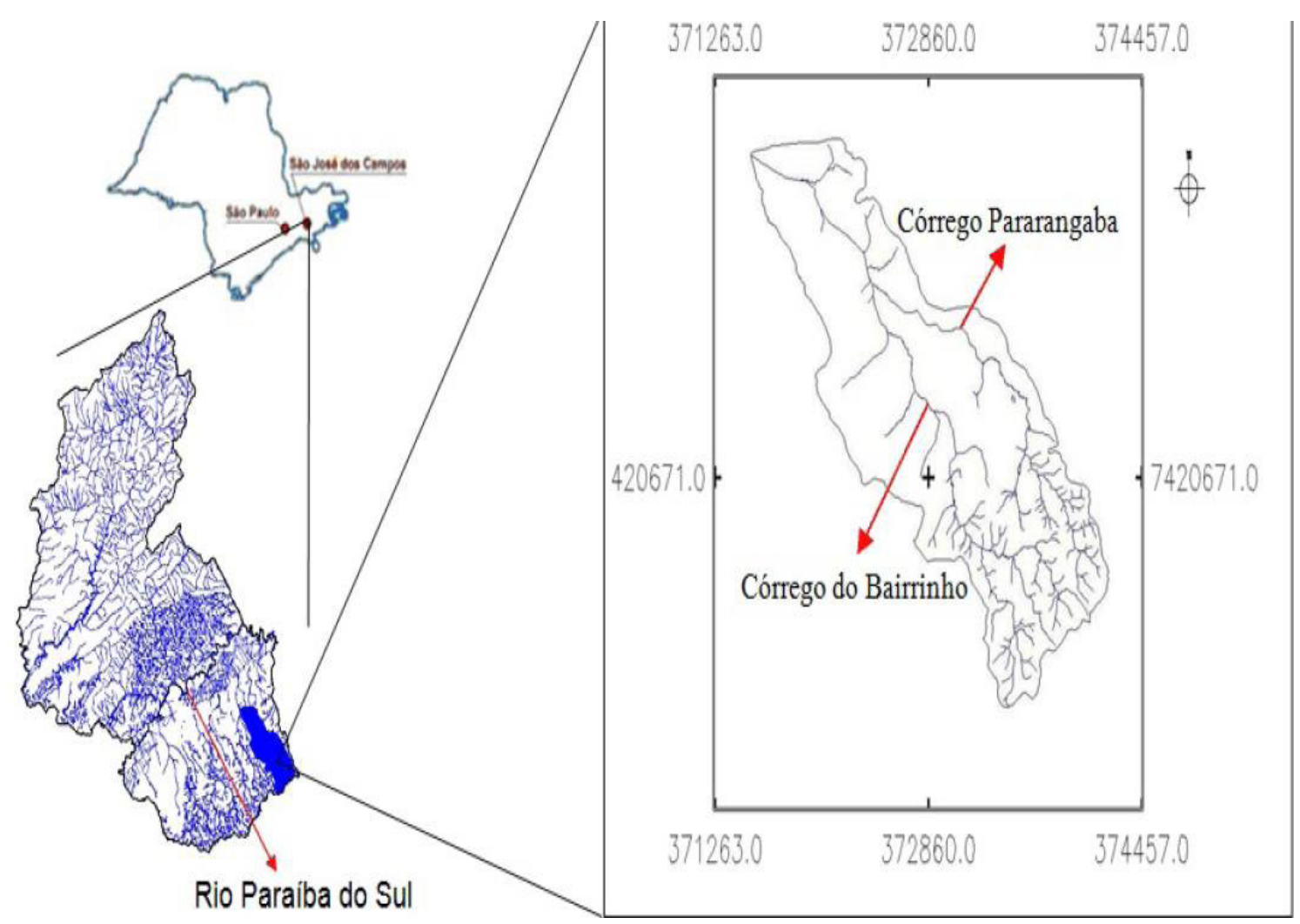

Figura 4: Localização córrego em relação ao rio Paraitinga e Paraibuna Fonte: NPPC, 2014

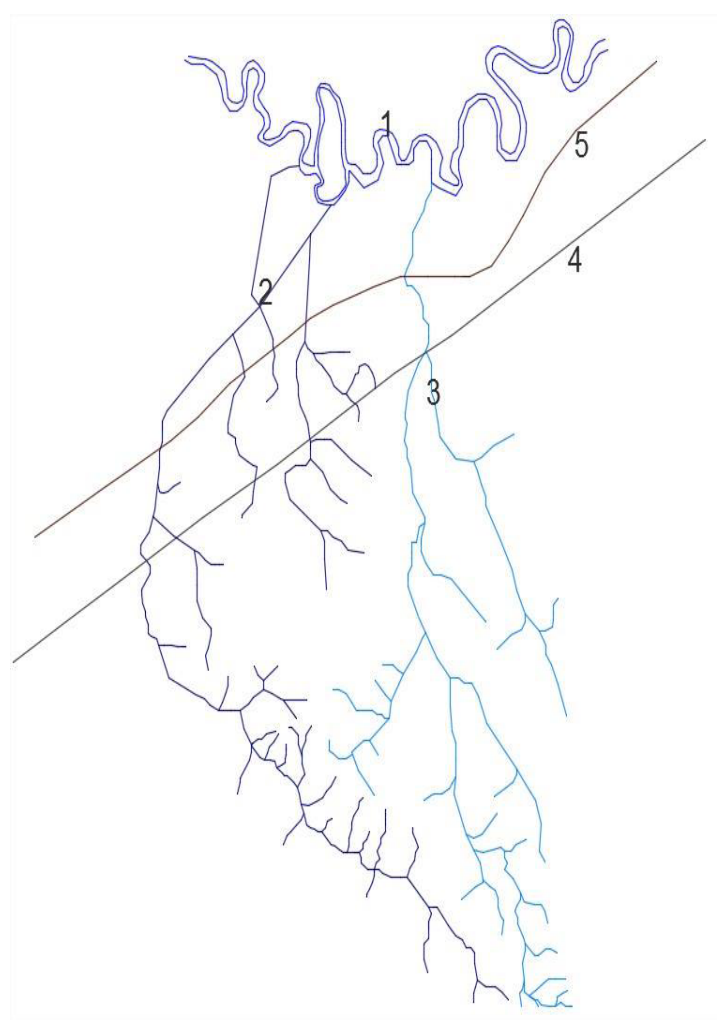

Identificação Hidrográfica

1. Rio Paraiba do Sul

2. Rio Pararangaba

3. Ribeirão Nossa Senhora da Ajuda do Bom Retiro

Rodovia e Ferrovia

4. Rodovia Presidente Dutra

5. Ferrovia

Figura 5: Identificação Hidrografica Fonte: NPPC, 2014 


\section{RESULTADOS E DISCUSSÃO}

\subsection{A CARACTERIZAÇÃO DA PAISAGEM HISTÓRICA}

Para a identificação das áreas de interesse histórico e cultural, utilizamos mapas e um acervo de base cartográfica histórica dos períodos entre 1920 a 2001 (SÃO JOSÉ DOS CAMPOS, 2013). A base cartográfica histórica foi compatibilizada para interpretação do patrimônio geomorfológico e identificação de áreas de interesse histórico cultural através do uso e da ocupação das terras neste período. Esta técnica que segue os princípios de iconografia histórica utilizou como base de estudo o mapa do IBGE de 1977 conforme figura 6.

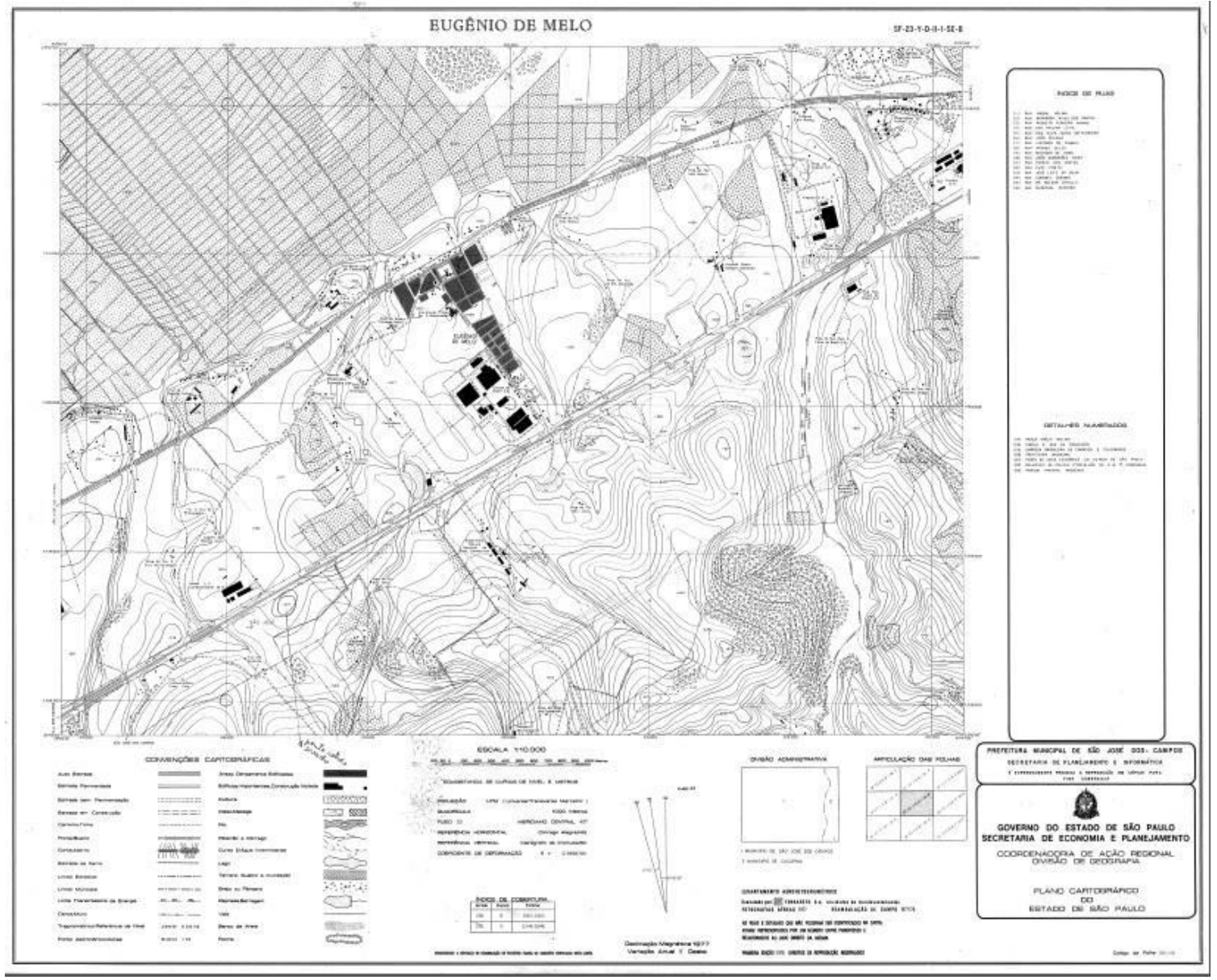

Figura 6: Mapa IBGE ano de 1977. Fonte: Adaptado pela autora (1977-IBGE).

A base de dados que um mapa com data mais antiga faz a metodologia da iconografia histórica partir do mais antigo para o mais novo. E é seguindo essa metodologia que escolhemos o mapa em questão e seguimos utilizando-o como base. Após esta definição, utilizamos a técnica de dados iconográficos históricos que identifica os patrimônios históricos para construção da base de dados e classificação dos bens culturais, segundo Pereira (2006) e levantamento dos indicadores para avaliação de áreas com patrimônio cultural e ambiental associado à caracterização geomorfológica histórica. Neste sentido então, começou-se uma proposta de enquadramento do patrimônio geomorfológico e do patrimônio paisagístico na organização temática do patrimônio, conforme mostra na Figura 8 que forma uma base que contempla todas as categorias 
patrimoniais existentes e suas interligações possíveis.

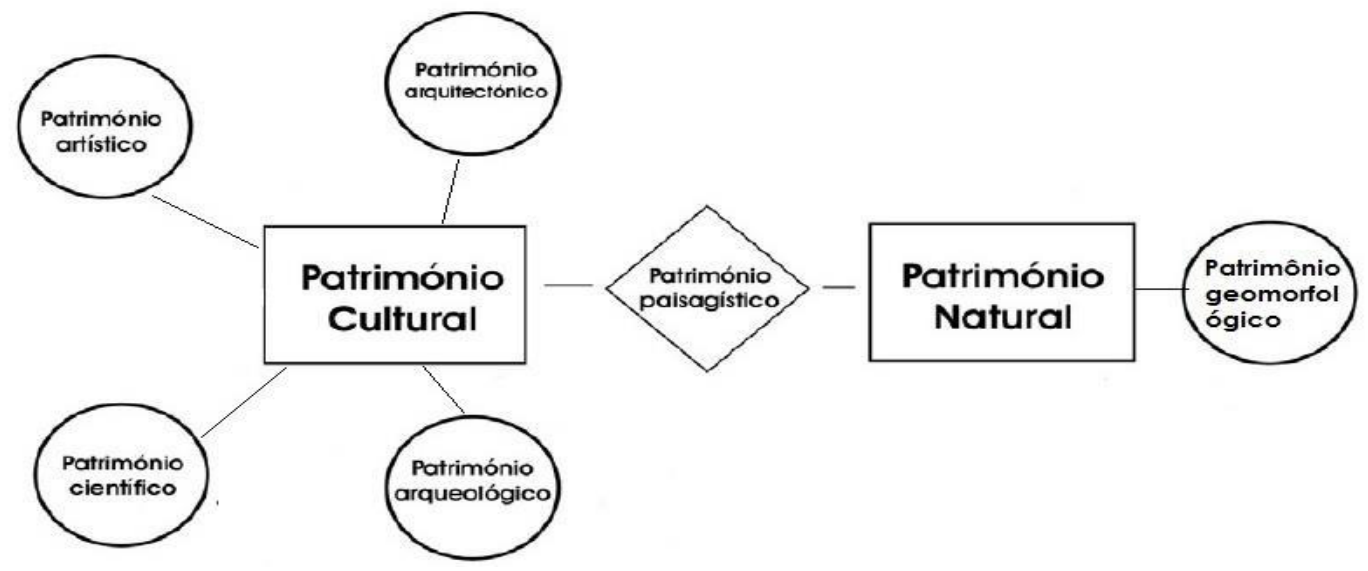

Figura 7: Proposta de enquadramento do patrimônio geomorfológico e do patrimônio paisagístico na organização temática do patrimônio. Fonte: Adaptação de PEREIRA, 2006.

Essa proposta de enquadramento forma uma base que contempla todas as categorias de uma determinada área em questão, porém podemos ressaltar que as categorias patrimoniais podem variar de acordo com os indicadores reais de cada área que esteja sendo estudada e de acordo com as informações contidas no mapa temático.

\subsection{A DELIMITAÇÃO DA ÁREA DE ABRANGÊNCIA NA PERCEPÇÃO VISUAL}

Para esta identificação da área de interesse paisagística, foram feitos trabalhos de campo no local para a realização da percepção visual que permitiram identificar a área e todos os elementos das referidas bases que foram ferramentas para a construção de cartas temática. Essas informações associadas aos dados da fundamentação teórica foram utilizadas para a seleção de indicadores. A princípio, a pesquisa limitou-se à área da percepção visual a um raio de $50 \mathrm{~m}$ da residência, que é uma área que obtivemos as melhores imagens do local. Porém, para a identificação de todos os principais elementos da área de estudo e da paisagem, adotamos um raio de $300 \mathrm{~m}$, para conseguirmos incluir todos os principais elementos que compõem a antiga fazenda Galo Branco.

Para levantamento da percepção visual, adaptamos a metodologia de Pereira (2006) analisando a paisagem do ponto de vista patrimonial para o natural, pois tivemos a imagem associada a uma percepção que resultou na paisagem.

\subsection{O PROCESSO DE IDENTIFICAÇÃO E DELIMITAÇÃO DA ÁREA DE PATRIMÔNIO CULTURAL}

A delimitação da área conforme podemos ver na Figura 6A é marcada por importantes barreiras como o córrego Nossa Senhora D’Ajuda do Bom Retiro que está na área limítrofe esquerda da área, que divide os municípios de São José dos Campos e Caçapava. Outra barreira conforme conseguimos identificar na delimitação da área é a linha férrea da estrada Eugênio de Mello que passa a frente da área da fazenda e está paralela a antiga estrada São Paulo-Rio que dá acesso à fazenda e outro limite importante à esquerda da delimita- 
ção da área é a divisa do Colégio "Embraer"; para fechar a área temos ao fundo a Rodovia Presidente Dutra.

Para essa pesquisa considerou-se como área de abrangência com valor histórico paisagístico de percepção visual um raio de $50 \mathrm{~m}$ em torno da residência histórica, pois é onde podemos ter a melhor amostra de percepção da paisagem histórica relevante do local. Para uma abrangência de todos os elementos que serão ferramentas para esta pesquisa, incluindo a vegetação, rio, estação, entornos entre outros que tornam desta paisagem o nosso meio de estudo, considerou-se um raio de $50 \mathrm{~m}$ que é utilizado pelo Instituto do Patrimônio Histórico e Artístico Nacional (IPHAN) para patrimônios históricos conforme podemos ver na Figura 9.

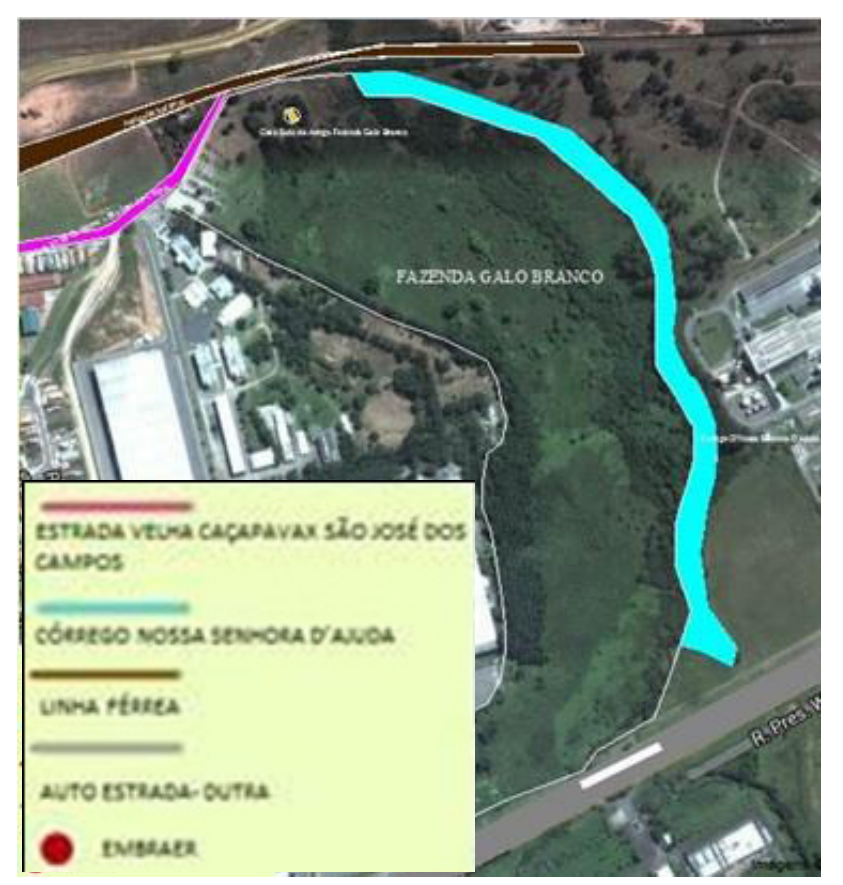

Figura 8: Delimitação da área de estudo: fazenda Galo Branco e suas barreiras físicas e naturais. Fonte: Google, 2014 


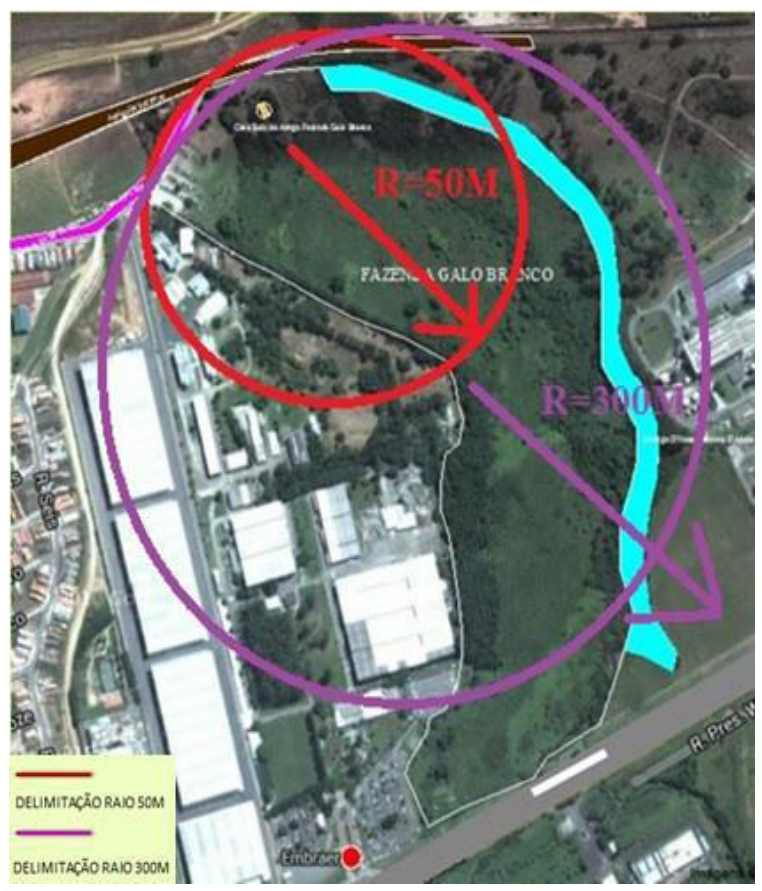

Figura 9: Delimitação da área de abrangência por meio da percepção visual e os raios adotados. Fonte: Google, 2014

A área de abrangência de percepção visual trata-se para a pesquisa de uma análise da paisagem como importância histórico-cultural e local; esta análise tende a incluir aspectos sócio-econômicos e histórico da população e a nova paisagem estabelecida no local nos dias atuais, através de levantamentos, mapas e registro fotográfico. Como estes itens, outros itens serão traçados e marcados para a conclusão de indicadores e a caracterização da área de estudo. Esta delimitação inicial da área foi fundamental para que nos situássemos perante a área e tomássemos o conhecimento que algumas barreiras seriam importantes não só para a área de estudo, mas para toda uma população.

\subsection{O PROCESSO DE IDENTIFICAÇÃO E DELIMITAÇÃO DA ÁREA HISTÓRICO-CULTURAL}

Para destacar as áreas importantes para o estudo, após a delimitação do raio, pela marcação do mapa temático podemos visualizar as principais características e delimitações da área, como a predominância da massa de vegetação existente nos limites da área, o córrego D' Nossa senhora D' Ajuda que tem papel fundamental na pesquisa com relação à característica geomorfológica da área e da caracterização do imóvel por ser uma fazenda cafeeira, entende-se que o rio teve relevante importância no traçado desta caracterização pela utilização da água para fonte de energia na época o que torou esse córrego um indicador limite para esta pesquisa.

Baseado neste enquadramento, ainda destacamos na área de estudo, as categorias de patrimônio existentes com a elaboração de uma legenda com cores destacando as áreas em questão. Para isso utilizou-se alguns métodos gráficos do programa de auto cad versão 2011 para aferir uma escala correta, este método que se mostrou eficiente consistiu em capturar uma imagem do Google Earth e através de referencia de escala impressa na imagem e algumas ferramentas do auto cad, chegássemos à escala correta. Em seguida des- 
tacamos as áreas de importância cultural, paisagística, arqueológica, arquitetônica, entre outras que fazem da fazenda Galo Branco como um todo, um patrimônio paisagístico a ser preservada para que tivéssemos em mãos um mapa que nos guiasse para as analises, levantamentos e próximos estudos, como apresentado na próxima figura:

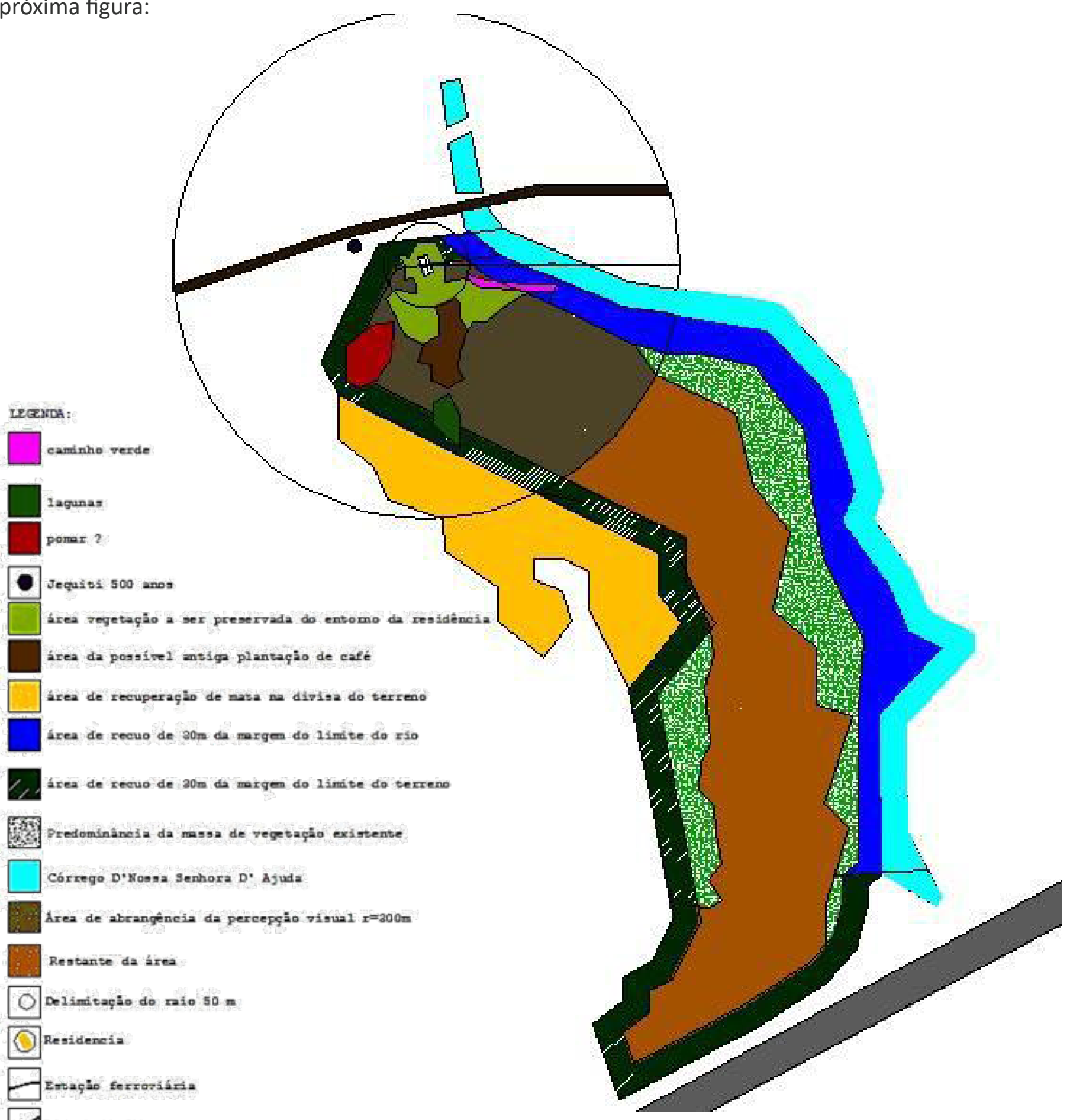

Figura 10: Mapa da caracterização e classificação da Fazenda Galo Branco, 2014. Fonte: GONÇALVES, 2014 
A classificação das legendas consistiu em uma análise pontual das áreas, como a área em torno da residência que tem grande importância arquitetônica e paisagística devido à memória datada na construção e a visão geral da fazenda que podemos fazer dos caminhos que podemos percorrer estando parados em torno da casa dentro do raio de 50 m estabelecidos e dos $300 \mathrm{~m}$.

Após esta análise, por meio dos dados gerados do mapa temático, pode-se aplicar a técnica da iconografia histórica através da adaptação realizada da Proposta de enquadramento do patrimônio geomorfológico e do patrimônio paisagístico na organização temática do patrimônio, onde foram então classificadas as áreas, conforme o gráfico adaptado com as nossas áreas de interesse da fazenda, o patrimônio cultural, ficou representado pela historia da fazenda e seu entorno; para o patrimônio arquitetônico, classificamos a casa que indicamos a elaboração de um projeto de restauro devido a sua grande importância arquitetônica para a fazenda e historia da população; para o patrimônio arqueológico, destacamos a área de plantio e secagem do café; para o patrimônio científico, destacamos a documentação e registros da fazenda; para o patrimônio artístico, destacamos a sede da fazenda; como patrimônio natural, classificamos dentro do mapa temático a vista do entorno, as paisagens formadas pelo conjunto da fazenda como um todo; como patrimônio geomorfológico classificamos a topografia e desenho do terreno que são ideais para a atividade de plantio de café e o córrego que permitiu que esta fazenda produzisse em abundância na época.

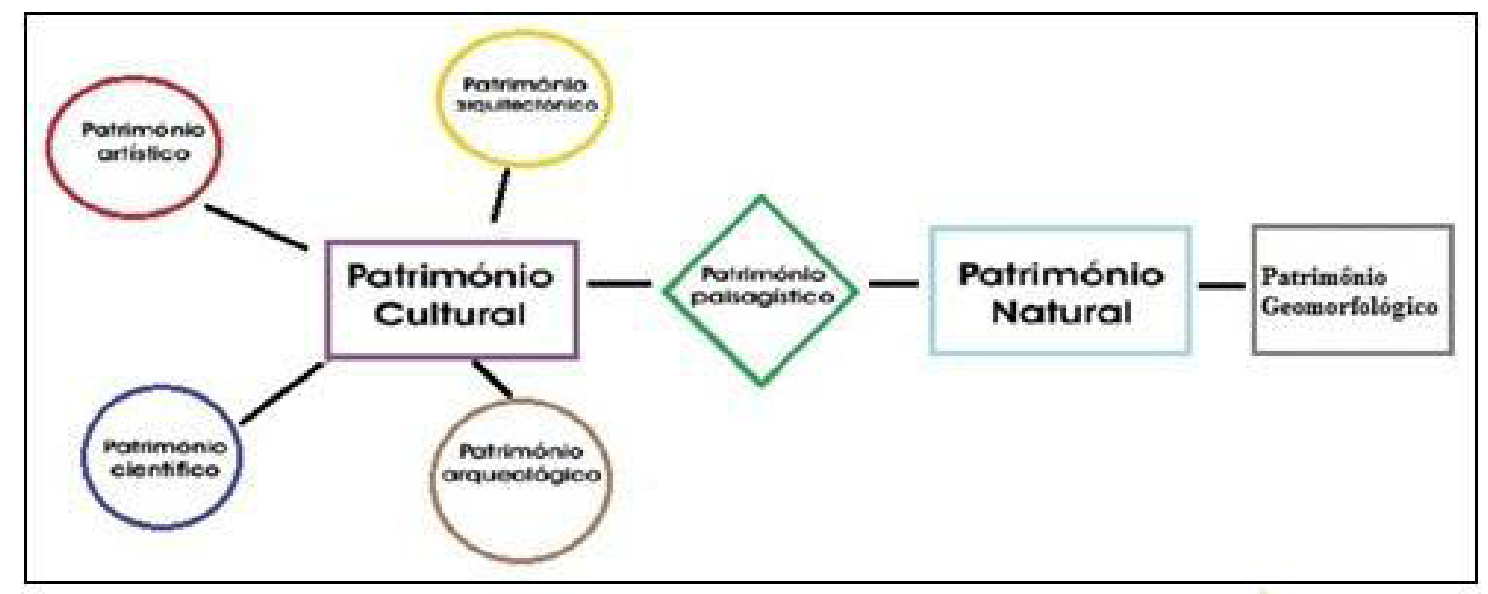

Figura 11: Enquadramento do patrimônio das áreas levantadas após análises. Fonte: Adaptado de PEREIRA, 2005

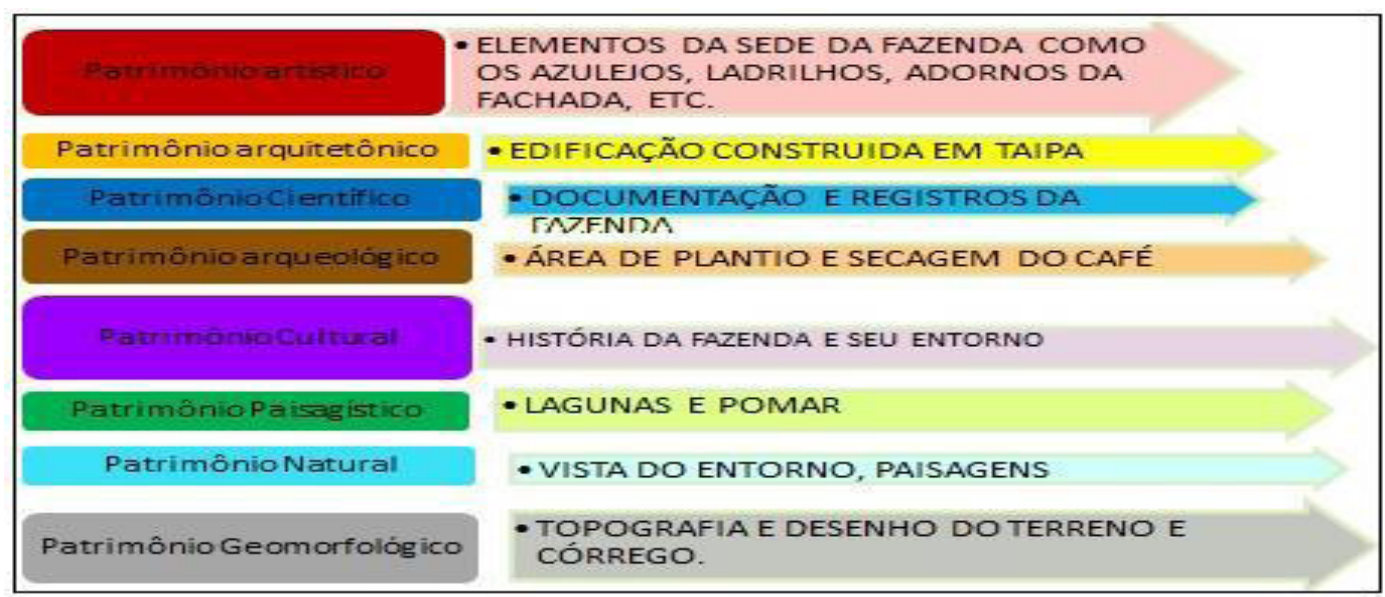

Figura 12: Enquadramento do patrimônio das áreas levantadas após análises. Fonte: GONÇALVES, 2014 


\subsection{O PROCESSO DE IDENTIFICAÇÃO E DELIMITAÇÃO DA ÁREA DE INTERESSE PAISAGÍSTICO}

Com as áreas do mapa temático classificadas a partir da adaptação das metodologias, partimos para o processo de identificação de áreas de interesse paisagístico, com a adaptação percepção que resultara na paisagem. Seguindo esse pensamento, partimos para o levantamento fotográfico onde pudemos detalhar características pontuais de cada área.

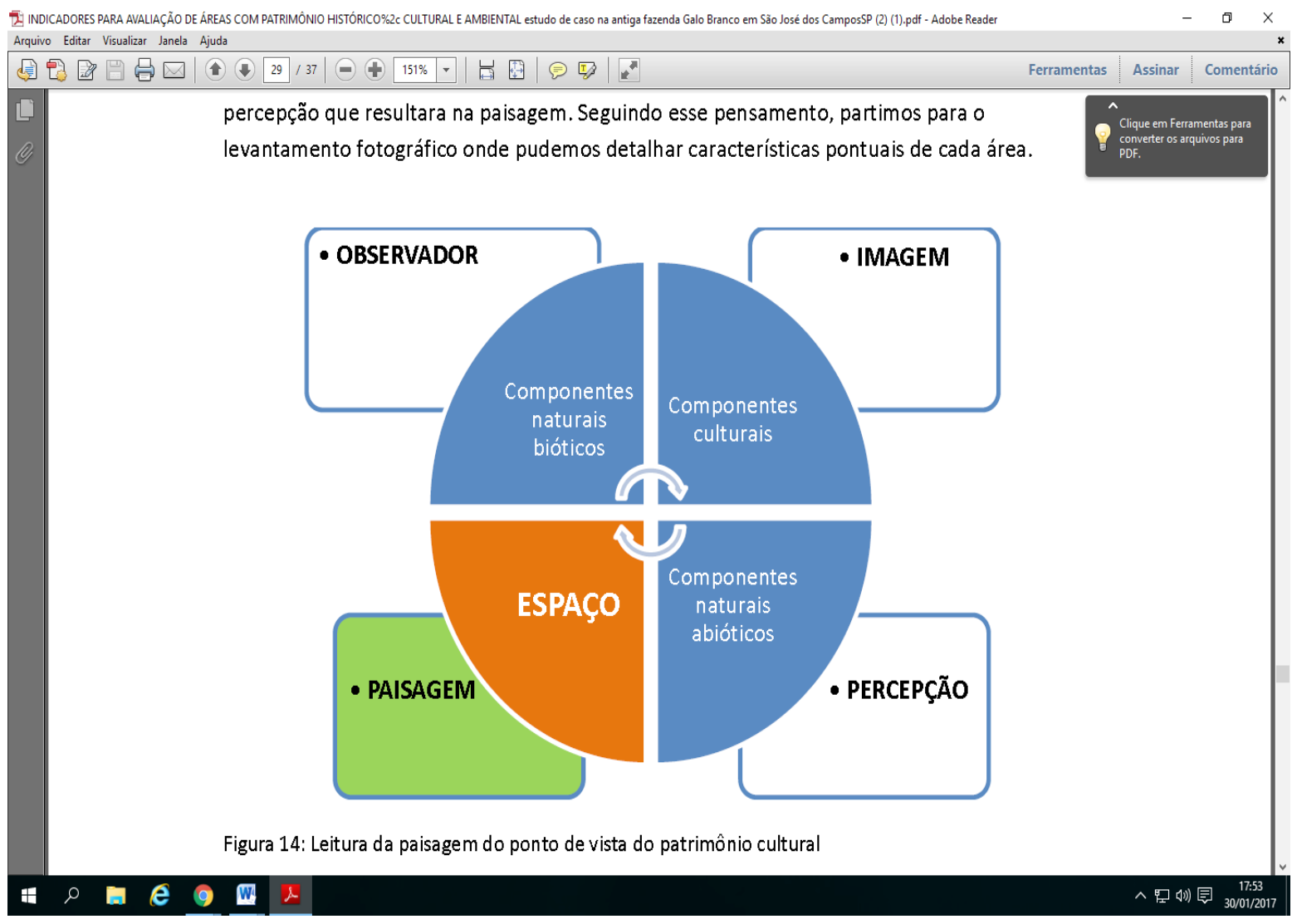

Figura 13: Leitura da paisagem do ponto de vista do patrimônio cultural. Fonte: GONÇALVES, 2014

O caminho verde, que liga a residência à margem do córrego Nossa Senhora d'Ajuda traz diversas espécies de plantas e vegetação que devem ser mantidas a fim de proteger as margens do rio e não descaracterizar o caminho verde conforme chamamos que é logo percebido de quem está na lateral da residência, indicador de um possível parque linear na área.

De costas para a parte dos fundos da casa, há uns $10 \mathrm{~m}$ de distância, encontra-se o que visivelmente entende-se que poderia ser a área de plantio e secagem do café, pois está situado na direção do tanque que fazia o abastecimento de agua da casa, e certamente fazia o abastecimento para irrigação das mudas de café. $\mathrm{Na}$ área vê-se ainda algumas evidências para esta área ser a de plantio, como o fato de ser a área mais plana visualizada na fazenda. De acordo com Laborie, 2014:

[...] quanto ás casas, sua exposição deve ser nos montes os mais accessíveis, e de ordinário na sumidade de alguns outeiros os mais extensos, e largos e menos íngremes, que se acharem, e para onde se possa conduzir água. Nelles se arranjam os diversos estabelecimentos, quanto pode ser, á vista, e alcance da casa de morada, e á indústria compete tirar da situação a mór vantagem possível. 
Localizados em caminhos atrás da residência, existem algumas lagunas, como foram chamadas, que se tratando de importância biológica, podem não ter significância, mas para a paisagem foram classificadas como lagunas que devem ser mantidas e preservadas, pois podem ser pontos de parada, com vegetação aquática e pequenos seres vivos que podem celebrar o caminho de quem anda pela fazenda, fazendo com que sejam imprescindíveis para o paisagismo do local, classificamo-las então, como patrimônio paisagístico local e indicador de um microclima sem alteração biótica.

Localizada à direita da parte de trás da casa, encontra-se hoje uma concentração de árvores frutíferas que formam uma bela sombra e caminho visivelmente marcado como uma das paisagens a serem preservadas, classificamos assim esta área como mais uma área de patrimônio paisagístico a ser mantida, como indicador de preservação de espécies frutíferas antigas dentro da área de estudo.

Em frente à fazenda existe um Jequitibá (Carinianalegalis (Mart.) Kuntze) de 500 anos que é mantido e tem importância paisagística para toda a região, assim incluímos como uma das paisagens mais importantes para a fazenda pois além de sua paisagem natural ela traz um ponto de referência importante para o local, a espécie é preservada pelos órgãos municipais do meio ambiente. As sementes desta espécie seriam os indicadores para reprodução de outras similares e, potencializaria o desenho da paisagem da área, associado às ações de educação ambiental.

Outra paisagem importante de destaque em frente à fazenda é da linha férrea que também foi destacada não somente a paisagem, mas pela sua importância atual e histórica para toda a população e que permitiu a na época da produção de café na fazenda, o transporte deste para cidades vizinhas. 

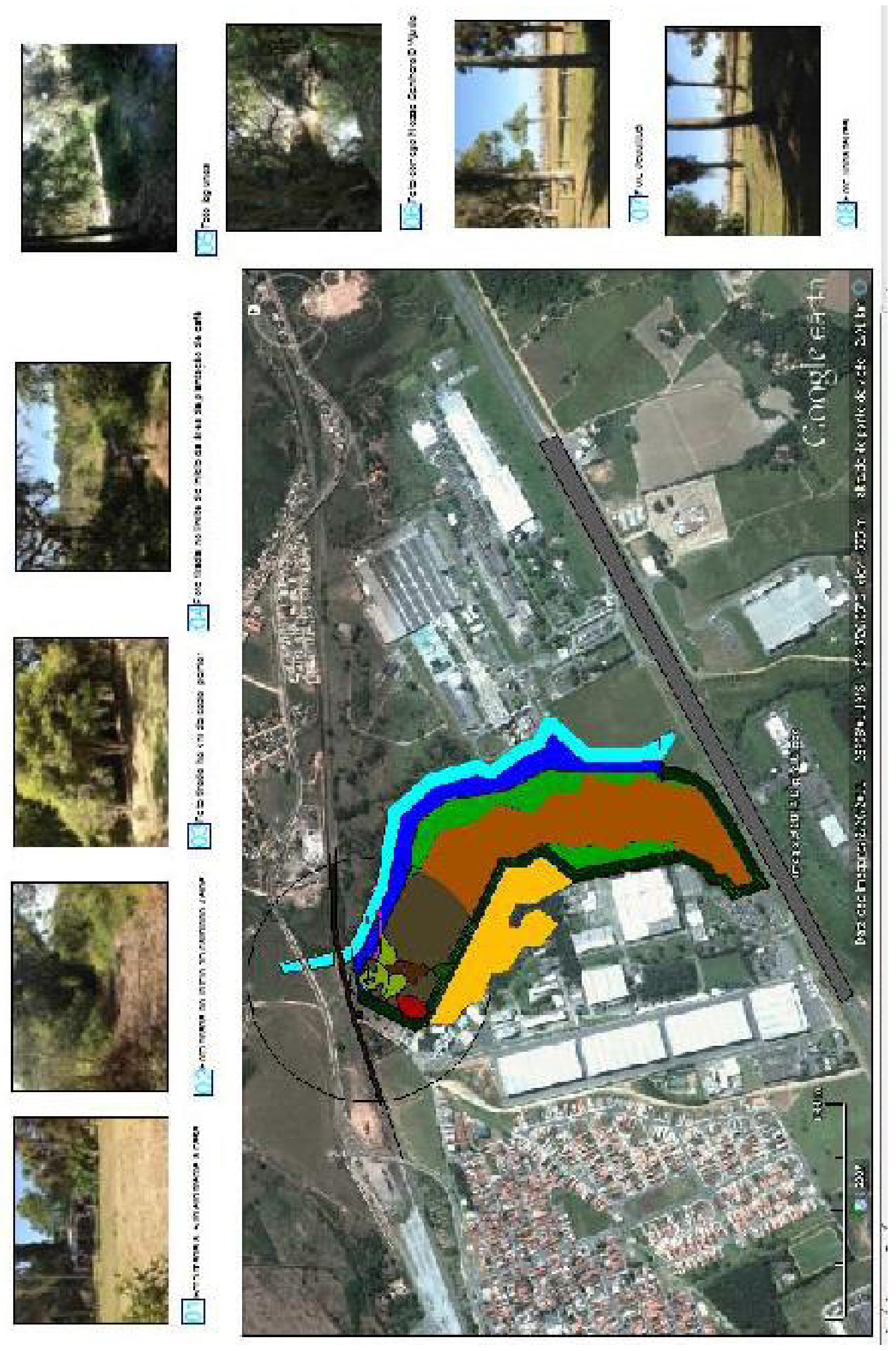

Figura 14 - Mapa de levantamento fotográfico e análises paisagísticas, 2014. Fonte: GONÇALVES, 2014 


\subsection{O PROCESSO DE IDENTIFICAÇÃO E DELIMITAÇÃO DA ÁREA DE PATRIMÔNIO GEOMOR- FOLÓGICO}

Para a identificação do patrimônio geomorfológico e caracterização da Fazenda Galo Branco, utilizamos o conceito que foi introduzido por (Alves 2006), adaptando| um gráfico onde mostra a potencialidade da área com as paisagens culturais, que seria a memória da população (baseado na documentação histórica como centenária da fazenda Galo Branco do cartório de registro de imóveis da cidade de São José dos Campos/SP) com relação àquela área e sua participação no período do café.

Aplicamos ainda outra metodologia de Alves (2006) que nos possibilitou uma análise mais profunda. Para a geoformas fluviais temos o córrego Nossa Senhora D’Ajuda que passa pela fazenda sendo o limite da área e que pode ter tido grande influência para a caracterização desta fazenda ser produtora de café. As geoformas paisagístico/naturais podemos observar na classificação da mata e solo da área. A geoforma férrea (infra- estrutura), também existe na área com a antiga linha férrea que delimita a área passando a frente da fazenda e a geoforma arquitetônica seria a casa sede da fazenda que passara por um projeto de restauro.

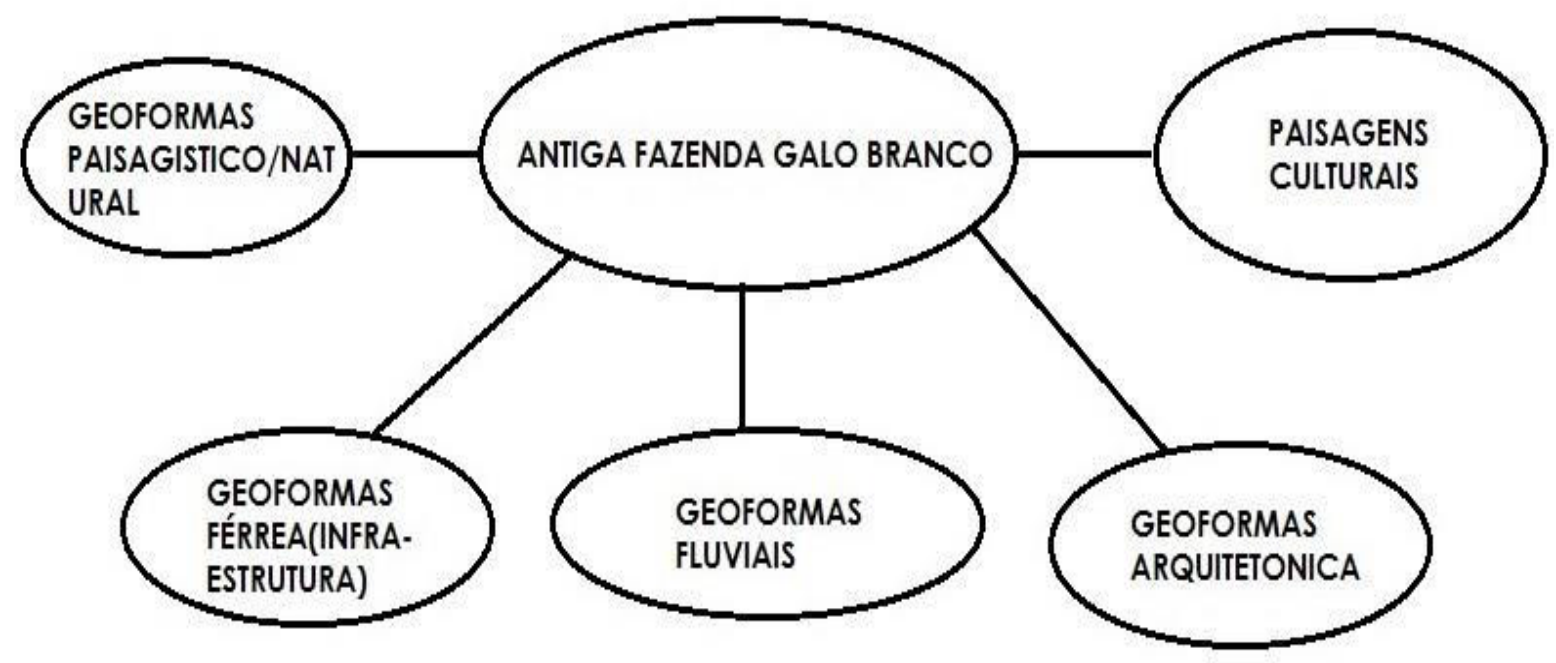

Figura 15 - Categorias temáticas do património geomorfológico da Fazenda Galo Branco. Fonte: GONÇALVES, 2014

\subsection{O PROCESSO E CARACTERIZAÇÃO DE INDICADORES DE BENS CULTURAIS E AMBIENTAIS}

Após a análise de dados históricos, os levantamentos in loco e a utilização de métodos adaptados como o de Pereira e Alves, pudemos destacar os indicadores, caracterizar e classificar de acordo com os dados levantados. Obtendo como resultado da percepção da paisagem histórica cultural, a leitura da área de estudo como um todo, porém destacando os tipos de patrimônio que a formavam, como a sede da fazendapatrimônio histórico; documentação e registros- patrimônio cientifico; área de plantio do café- patrimônio da paisagem histórica (recomposição); lagunas e pomar- patrimônio paisagístico; paisagens-patrimônio natural; córrego- patrimônio geomorfológico; Casa dos colonos, tulha, roda d'água, terreiro, rancho, cocheira, garagem, paiol. - patrimônio arqueológico. A especificação foi feita por meio da área total delimitada da área de estudo e a área pontual de cada indicador em questão para que tivéssemos o dado quantitativo de quanto o indicador esta inserido na área de estudo, conforme a tabela: 


\begin{tabular}{|c|c|c|c|}
\hline Classificação & Indicador & Caracterização & $\begin{array}{l}\text { Es p e cific a ção } \\
\text { (porcentagem de ocupa- } \\
\text { ção com relação à área } \\
\text { total delimitada para } \\
\text { área de estudo - preser- } \\
\text { vação paisagista e am- } \\
\text { biental, } 15.000 \mathrm{~m}^{2} \text { ) }\end{array}$ \\
\hline $\begin{array}{l}\text { Patrimônio ar- } \\
\text { quitetônico }\end{array}$ & $\begin{array}{l}\text { Sede da } \\
\text { Fazenda }\end{array}$ & $\begin{array}{l}\text { Construção de tai- } \\
\text { pa do ano de } 1920\end{array}$ & $0,6 \%$ \\
\hline $\begin{array}{l}\text { Pat rimôn io } \\
\text { Científico }\end{array}$ & $\begin{array}{l}\text { Documen- } \\
\text { tação e registros }\end{array}$ & $\begin{array}{l}\text { História e dados da } \\
\text { fazenda levantados atra- } \\
\text { vés do registro de imóveis } \\
\text { (centenária) da fazenda e } \\
\text { levantamentos in loco. }\end{array}$ & - \\
\hline $\begin{array}{l}\text { Patrimônio } \\
\text { paisagem histórica } \\
\text { (recomposição) }\end{array}$ & $\begin{array}{l}\text { Área de } \\
\text { plantio do café }\end{array}$ & $\begin{array}{l}\text { Características de } \\
\text { uma área para recompo- } \\
\text { sição de paisagem histó- } \\
\text { rica, pois possui as carac- } \\
\text { terísticas para este tipo } \\
\text { de atividade, mas não te- } \\
\text { mos mais os vestígios. }\end{array}$ & $3,19 \%$ \\
\hline $\begin{array}{l}\text { Pa trimôn i o } \\
\text { paisagístico }\end{array}$ & $\begin{array}{l}\text { Lagunas } \mathrm{e} \\
\text { pomar }\end{array}$ & $\begin{array}{l}\text { Características bioló- } \\
\text { gicas e naturais. }\end{array}$ & $\begin{array}{l}\text { 1,15\% (laguna) e } \\
7,10 \% \text { (Pomar) }\end{array}$ \\
\hline $\begin{array}{l}\text { Patrimônio na- } \\
\text { tural }\end{array}$ & Paisagens & $\begin{array}{l}\text { Características na- } \\
\text { turais constituído de bens } \\
\text { materiais e imateriais que } \\
\text { se referem á identidade } \\
\text { da sociedade local e sua } \\
\text { história a partir de dados } \\
\text { envolvendo ainda dados } \\
\text { de geodiversidade e fato- } \\
\text { res bióticos de formação } \\
\text { natural, mas que podem } \\
\text { ter tido interferência hu- } \\
\text { mana. }\end{array}$ & 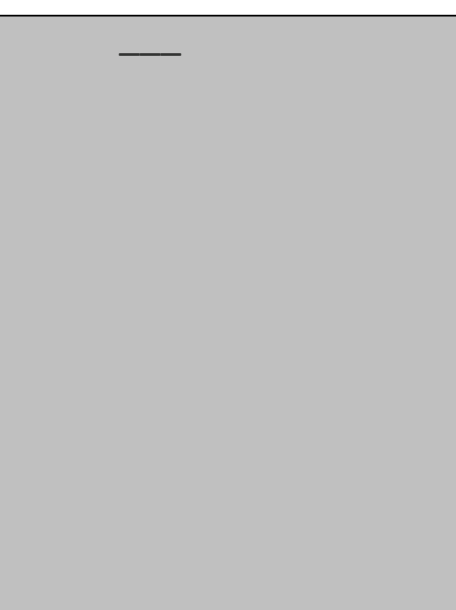 \\
\hline
\end{tabular}




\begin{tabular}{|c|c|l|c|}
\hline $\begin{array}{c}\text { Patrimônio Ge- } \\
\text { omorfológico }\end{array}$ & Córrego & $\begin{array}{c}\text { Características ge- } \\
\text { ológicas que são analisa- } \\
\text { das como paisagem le- } \\
\text { vando em consideração } \\
\text { todo o conjunto de uma } \\
\text { área e não somente um } \\
\text { patrimônio isolado como } \\
\text { uma análise de patrimô- } \\
\text { nio arquitetônico. }\end{array}$ & $17,35 \%$ \\
\hline queológico & $\begin{array}{l}\text { Casa dos } \\
\text { colonos, tulha, } \\
\text { roda d'água, ter- } \\
\text { reiro, rancho, co- } \\
\text { cheira, garagem, } \\
\text { paiol. }\end{array}$ & $\begin{array}{l}\text { Categorias de bens cul- } \\
\text { turais e históricas da fa- } \\
\text { zenda que retratam e } \\
\text { confirmam a utilização da } \\
\text { fazenda como produtora } \\
\text { cafeeira devido à infra es- } \\
\text { trutura encontrada. }\end{array}$ & $2,24 \%$ \\
\hline
\end{tabular}

Tabela 1: Tabela de classificação e caracterização dos indicadores e sua especificação em porcentagem com relação á área total de estudo. Fonte:.GONÇALVES,2014

\section{CONCLUSÃO}

A Pesquisa conclui que a seleção de indicadores para avaliação de áreas com patrimônio histórico cultural e ambiental em grande escala, como no caso da antiga fazenda galo branco em são josé dos campos/sp é possível através de metodologias de levantamento e análises de todas as características histórica e físicas do local.

A caracterização na fazenda Galo Branco para inventariação, caracterização e classificação do patrimônio histórico cultural associado á caracterização geomorfológica foi suficiente para que tivéssemos conhecimento total da área e sua classificação pois é uma área de preservação natural com valor histórico cultural e que a partir deste trabalho a população poderá conhecer melhor e reconhecer a história da região a partir daquela fazenda que um dia foi uma grande produtora de café e empregadora e deixou marcas para que pudéssemos hoje entendê- la como um todo. Assim como sua classificação, a partir dos levantamentos, ainda pudemos destacar algumas medidas que colocamos no trabalho como sugestões que seria sobre o córrego que poderia ser recuperado e mantido para a saúde da fazenda e de toda a região, digo o córrego como paisagem e suas margens mas também pelas suas águas e traçado que são primordiais para a geografia natural da região e para toda a população. Outra medida foi percebida analisando a imagem aérea pelo google Earth da área da fazenda e descrevemos como uma área de conflito entre a delimitação fazenda antiga com a área de ocupação da EMBRAER pois detectamos uma área que está próxima a cerca de divisa da fazenda com a área dos galpões da Embraer e isto é preocupante pois se não houver um limite de quantidade de avanço para dentro da área da fazenda, a paisagem como um todo pode ser ameaçada. Por isso sugere-se recuperar esta área com vegetação, colocando ainda uma vegetação um pouco mais alta afim de não permitir também uma poluição da paisagem neste lado da paisagem pelos galpões e adotou-se um recuo de $30 \mathrm{~m}$ como o 
recuo que temos do córrego para que nada venha interferir na área futuramente. Com essas análises concluímos então que os resultados foram satisfatórios e dignos de serem aprofundados.

\section{REFERÊNCIAS}

BRASIL, (1988)- Constituição da República Federativa do Brasil.

BRASIL. Constituição (2010). Constituição da República Federativa do Brasil. Brasília, DF, Senado,2010.

CARVALHO A. G. (1999) - Geomonumentos - uma reflexão sobre a sua caracterização e enquadramentonum projecto nacional de defesa e valorização do Património Natural. Liga deAmigos de Conímbriga, Lisboa, 30 p.

CASTELEIRO.J. Dicionário da Língua Portuguesa Contemporânea. .Lisboa: Verbo, 2000. 1959p.

CERQUEIRA. (1996). A iconografia dos vasos gregos antigos como fonte histórica. Universidade de São Paulo, $7 p$

CONFERENCIA GERAL UNESCO da Organização das Nações Unidas para Educação, a Ciência e a Cultura, reunida em Paris, de 17 de outubro a 21 de novembro de 1972

DEPONTI(2001) Indicadores para avaliação da sustentabilidade em contextos de desenvolvimento rural local .Universidade Federal do Rio Grande do Sul. Porto Alegre, 2001. 165p.

DEPONTI.(2002) Estratégia para a construção de indicadores para avaliação da sustentabilidade e monitoramento de sistemas. Agroecol. eDesenvol. Rur. Sustent. Porto Alegre, v.3, n.4, out/dez 2002

EMBRAER.(2013) Instituto Embraer. www.institutoembraer.com.bracessado em 20 de junho de 2013

FERNANDES J. P. (Dir.) (2004) - Dicionário Jurídico da Administração Pública, INA, Vol. VI, 674 p.

GALLOPIN, 1977, BOSSEL, 1999, United nations division for Sustainable development, 2001.

GRANDGIRARD, E. Geomorphosite assessment in Montesinho Natural Park. Portugal, 1997.

GRAY.M. (2004) - Geodiversity. Valuing and conserving abiotic nature. Wiley, $412 \mathrm{p.}$

http://periodicos.puc-campinas.edu.br/seer/index.php/oculum/article/view/1450/1424 - (OLIVEIRA \& FERRÃO, 2012) http://www.bibliotecadigital.unicamp.br/document/?code=000478239\&fd=y (SCARIATO,2009)

http://www.scielo.br/pdf/his/v26n2/a13v26n2.pdf (NOGUEIRA, 2007)

IPHAN, 2004 Disponível em: http://portal.iphan.gov.br/baixaFcdAnexo.do?id=418 preciso da data de acesso - não tem título

O fazendeiro de café da ilha de São Domingos, de P. J. LaborieSEEC, Secretaria do Estado da Cultura do Paraná. Conceito de Tombamento. SEEC: Curitiba,2014. Disponível: http://www.patrimoniocultural.pr.gov.br/modules/conteudo/ conteudo.php?conteudo=4

PEREIRA(2006).Património geomorfológico: da actualidade internacional do tema ao caso português. Centro de Ciências da Terra, Universidade do Minho, Braga.

PEREIRA.P.(1995) Universidade do Minho: centro de ciências da terra. In: repositorium.sdum.uminho.pt/bitstream/1822/13785/1/e02_003.pdf acesso disponível em 25 de junho de 2013.

Prefeitura do Rio de Janeiro. Instituto do Patrimônio Cultural, Intervenção Urbana, Arquitetura e Design. APAC,1992. Disponível:http://www0.rio.rj.gov.br/patrimonio/apac.shtm

São Jose dos Campos. Registro de imóveis e anexos: certidão emitida em 26/07/2013. São José dos Campos: São Paulo, 2013.

UNITAU. Seminário da disciplina bacias hidrográficas: meio ambiente e sociedade. in: programa de pós graduação em ciências ambientais da Universidade de Taubaté, 2012. 